\title{
Study on the Antioxidative and Physiological Activities of Saururus chinensis Extract
}

\author{
Chang Soo Kang', Min Joo Lee ${ }^{1}$ Cheol Bem Park ${ }^{2}$ and In Seok Bang ${ }^{1}$ * \\ ${ }^{1}$ Department of Biological Science and the Research Institute for Basic Sciences, Hoseo University, Asan 336-795, Korea \\ ${ }^{2}$ Fusion Technology, Hoseo University, Asan 336-795, Korea
}

Received March 24, 2012 /Revised June 1, 2012 / Accepted June 6, 2012

\begin{abstract}
Saururus chinensis has long been widely used in oriental folk medicines to treat diseases. In the current study, organic solvent fractions obtained from the main methanolic extract of $S$ chinensis were evaluated for their antioxidative and related physiological activities. The antioxidant activity of the fractions was measured using DPPH free radical scavenging activity, increased in a dose-dependent manner, and the $\mathrm{ED}_{50}$ of the ethyl acetate fractions exhibited a value of $12.84 \mathrm{\mu g} / \mathrm{ml}$ higher than 27.22 $\mu \mathrm{g} / \mathrm{ml}$ compared to the BHT. Also, the cell viability of $S$. chinensis on $\mathrm{H}_{2} \mathrm{O}_{2}$-induced HDF cell death $\left(\mathrm{IC}_{50}\right)$ showed the highest cell viability of $89.39 \%$ in $50 \mu \mathrm{g} / \mathrm{ml}$ of ethyl acetate fraction and $67.98 \%$ of visible cell survival rate in $n$-butanolic fraction. Meanwhile, all fractions of the $S$. chinensis extract led to a slight down regulation of the mRNA expression of fibulin-5, which is related to skin elasticity, and the ethyl acetate fraction having high antioxidant activity showed a markedly inhibitory effect on chick embryonic angiogenesis using the CAM assay. These results suggest that the ethyl acetate fraction of $S$. chinensis extract could be a good material in therapeutic application for antioxidant and related anti-angiogenesis activities.
\end{abstract}

Key words : Saururus chinensis, antioxidant activity, angiogenesis, CAM assay

\section{서 론}

모든 생명체는 생체 내에서 산소를 전자수용체로 하는 호흡 을 통해 에너지를 획득하게 되는데 흡입된 대부분의 산소는 대사과정에서 안전한 물 $\left(\mathrm{H}_{2} \mathrm{O}\right)$ 로 환원되지만 일부분은 반응성 이 매우 큰 활성산소종(reactive oxygen species, ROS)과 활성 질소종(reactive nitrogen species, RNS)으로 전환된다[10,18]. 활성산소는 생체 내 superoxide dismutase (SOD), catalase, peroxidase 등과 같은 효소의 항산화기작에 의해 대부분 소멸 된다. 그러나 활성산소가 정상적으로 소거되지 않을 때 자유 라디칼(free radical)로 인한 산화적 스트레스가 생체 내에 가 해져 세포구성 성분들인 지질, 단백질, 당, DNA 등에 대하여 비선택적, 비가역적인 파괴작용을 나타냄으로써 노화는 물론 성인병과 암을 비롯하여 각종 질병을 일으키는 원인이 되고 있다 $[4,9,11]$. 특히 성인병 질환의 원인이 활성산소에 기인된 것이라는 학설이 점차 인정되어짐에 따라 활성산소를 조절할 수 있는 물질인 항산화제에 대한 관심이 증대되고 있다[30]. 활성산소의 독성을 억제하기 위한 항산화제로는 butylated hydroxyanisole (BHA), butylated hydroxytoluene (BHT)와 같은 합성 항산화제와 tocopherol과 같은 천연 항산화제가 있 다. Tocopherol은 천연 항산화제이지만 가격이 높고, $\mathrm{BHA}$ 와

\footnotetext{
*Corresponding author

Tel : +82-41-540-9595, Fax : +82-41-548-6231

E-mail : isbang@hoseo.edu
}

$\mathrm{BHT}$ 는 우수한 항산화능력을 보이고 있지만 과량으로 섭취할 경우 암 유발 가능성 등의 안정성이 논란이 되고 있다[22]. 따 라서 생체 내 무해하면서 항산화 방어 시스템을 증가시키거나 활성산소를 조절할 수 있는 합성 또는 천연 항산화제 개발연 구의 필요성이 강조되고 있고 이에 대한 탐색이 활발히 진행 되고 있다[16,33].

삼백초(Saururus chinensis)는 한의학을 비롯한 민간요법에 서 전초는 습열, 청리, 소독, 해독의 효능이 있어 부종, 각기, 황달, 임탁, 대하, 옹종, 정독의 치료에 쓰이며, 뿌리는 이수, 제습, 청열, 해독의 효능이 있어 각기, 경종, 임탁, 대하, 옹종, 개선의 치료에 사용되고 있다 $[25,26,29]$. 근래 삼백초에 관한 천연물 연구를 통하여 항산화 활성[8,31], 항균 활성[15,17], 항 암 활성[27], 미백작용[19,24] 및 진통성분[28] 등 다양한 생리 활성이 규명되었다. 삼백초의 주요 정유성분은 methyl-n-nonyl-ketone이며, 잎에는 quercetin, quercitrin, isoquercitrin, avicularin, hyperin, rutin 및 가수분해성 tannin, 줄기에는 가 수분해성 tannin, 그리고 뿌리에는 아미노산, 유기산, 당류 및 가수분해성 tannin이 함유되어 있다[20,21]. 특히 삼백초의 주 성분인 quercetin과 quercitrin은 flavonoid의 일종으로 항균 및 항산화 효과를 나타내는 것으로 보고되며, 최근 항암성 및 모세혈관 강화작용 등의 효과들이 알려져 있다[14,32].

본 연구에서는 약용으로 사용되고 있는 삼백초 $\mathrm{MeOH}$ 추 출물의 유기 용매 분획물이 항산화 효과와 연관하여 피부의 탄력 및 혈관형성에 미치는 영향을 조사하여 천연물에 존재하 는 생리활성 물질의 개발 가능성을 알아보았다. 


\section{재료 및 방법}

\section{재료 및 시약}

본 실험에 사용된 삼백초는 경동시장에서 건조 상태의 잎과 줄기를 구입하여 쇄절 후 실험에 사용하였다. 추출 및 분획 용매로 methanol $(\mathrm{MeOH}), n$-hexane, chroloform $\left(\mathrm{CHCl}_{3}\right)$, ethyl acetate (EtOAc), $n$-butanol $(n-\mathrm{BuOH})$ 은 Duksan Co. (Korea)로부터 구입하여 사용하였다. 항산화 활성 실험을 위 하여 BHT, 1,1-dipheyl-2-picyl-hydrazyl (DPPH), hydrogen peroxide $\left(\mathrm{H}_{2} \mathrm{O}_{2}\right)$ 및 MTT assay 시약은 Sigma Chemical (USA) 제품을, chorioallantoic membrane (CAM) assay를 위 하여 retinoic acid, thermanox coverslip은 각각 Sigma와 Nunc (USA) 제품을 사용하였다. Total RNA 분리는 acid-phenol 추출법을 이용한 RNeasy kit (Qiagen, Germany)를 사용 하였으며 그 밖의 실험에 사용된 모든 시약은 특급 제품을 구입하여 사용하였다. 인간 피부 섬유아세포(human dermal fibroblast, HDF)는 한국세포주은행(Korea cell line bank, Seoul, Korea)에서 분양받았고, 세포 배양에 사용된 Dulbecco's Modified eagle medium (DMEM) 및 항미생물질 은 Hyclone (USA)에서, fetal bovine serum (FBS)은 Sigma-Aldrich (USA)에서 각각 구입하였다.

\section{시료의 추출 및 분획}

쇄절한 삼백초 $200 \mathrm{~g}$ 에 $1 \mathrm{liter}$ 의 $\mathrm{MeOH}$ 을 가하여 상온에서 24 시간씩 교반하면서 3회 반복 추출한 후, 여과시켜 $80^{\circ} \mathrm{C}$ 항온 수조(Oilbath, Switzerland)에서 회전 감압농축기(Rotavapor, Switzerland)로 감압하여 농축물인 $\mathrm{MeOH}$ 추출물 $7.311 \mathrm{~g}$ 을 얻었다. $\mathrm{MeOH}$ 추출물, 증류수 그리고 $n$-hexane을 1:9:10의 비율로 혼합하여 물 층과 분획 용매가 두 층으로 나뉘도록 방치하여 3 회 분획된 $n$-hexane 가용부를 감압 농축하여 $n$-hexane 분획 $0.289 \mathrm{~g}$ 을 얻었다. 계속하여 잔류층인 수층을 $\mathrm{CHCl}_{3}, \mathrm{EtOAc}, n-\mathrm{BuOH}$, water 순으로 각각 3 회씩 용매의 극 성을 이용한 순차적 분획으로 $0.397 \mathrm{~g}, 0.282 \mathrm{~g}, 1.024 \mathrm{~g}$ 그리고 $3.120 \mathrm{~g}$ 의 분획물 각각을 얻었다(Fig. 1).

\section{$\mathrm{DPPH}$ 자유라디칼 소거법에 의한 항산화 활성}

삼백초 추출물의 극성별 분획물에 대한 항산화 활성은 $\mathrm{DPPH}$ 의 자유라디칼 소거효과(free radical scavenging effect) 를 측정하는 Blois[6]의 방법을 변형하여 활용하였다. $\mathrm{MeOH}$ 에 녹인 $0.2 \mathrm{mM} \mathrm{DPPH}$ 용액 $900 \mu \mathrm{l}$ 에 $\mathrm{MeOH}$ 에 용해시킨 각 분획물의 농도별 시료 $100 \mu 1$ 를 혼합하여 실온에서 30 분간 암 실에서 방치 후 $517 \mathrm{~nm}$ 에서 흡광도를 측정하였다. 양성 대조 물로는 BHT을 사용하였고, 시료의 전자공여능(electron donating ability, EDA)은 다음의 식으로 계산하였다.

$\operatorname{EDA}(\%)=(1-\mathrm{A} / \mathrm{B}) \times 100$

$\mathrm{A}: 517 \mathrm{~nm}$ 에서의 시료첨가구의 흡광도

B: $517 \mathrm{~nm}$ 에서의 무첨가구의 흡광도

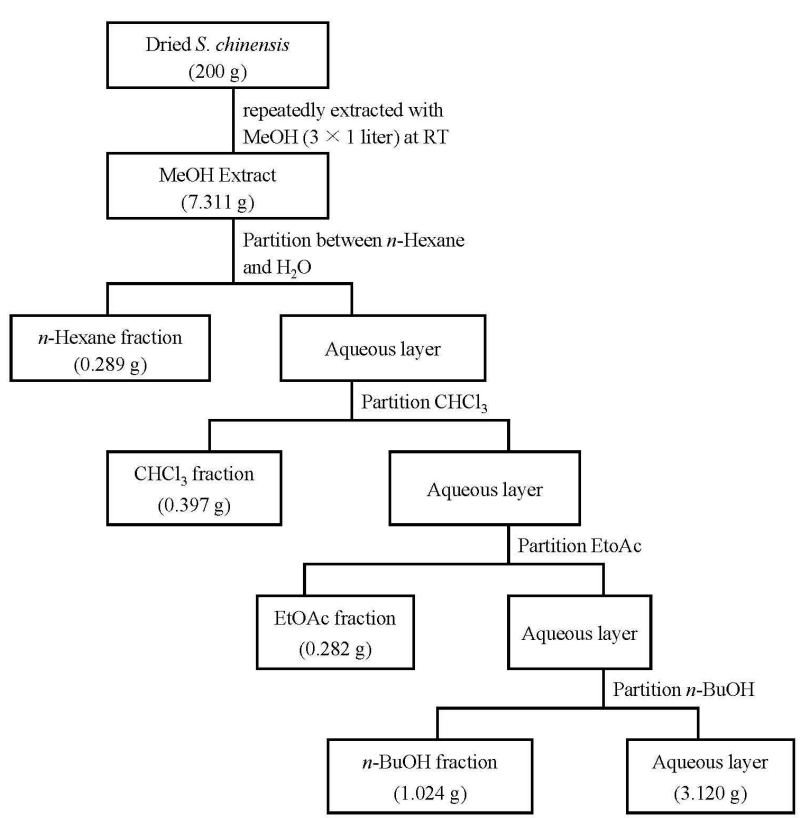

Fig. 1. Schematic diagram of extraction and fractionation of $S$. chinensis.

각 분획물의 $\mathrm{EDA}(\%)$ 값을 바탕으로 흡광도를 $50 \%$ 감소시 키는데 필요한 시료의 양 $\mathrm{ED}_{50}(\mathrm{~kg} / \mathrm{ml})$ 을 구하고, $\mathrm{BHT}$ 와 비교 하여 항산화 활성을 검정하였다.

\section{삼백초 추출 분획물 및 $\mathrm{H} 2 \mathrm{O} 2$ 의 세포독성과 분획별 세포사} 멸 보호능

$\mathrm{HDF}$ 세포에 대한 각 추출 분획물 및 $\mathrm{H}_{2} \mathrm{O}_{2}$ 의 세포독성, 각 분획물의 $\mathrm{H}_{2} \mathrm{O}_{2}$ 로부터의 세포손상 보호능을 아래의 MTT assay로 측정하였다. $\mathrm{HDF}$ 세포를 $1 \times 10^{5} \mathrm{cell} / \mathrm{ml}$ 의 농도로 100 ul씩 96 well plate에 접종한 후 70 80\% confluency가 되었을 때 삼백초 추출 분획물을 각 농도별로 처리하여 48 시간 배양 한 후 세포 생존율을 분석하였다. $\mathrm{H}_{2} \mathrm{O}_{2}$ 처리에 의한 세포독성 은 위의 순서에 따르되 10 100 $\mu \mathrm{M}$ 의 농도로 처리하여 24시 간 배양한 후 세포 생존율을 분석하였다. 또한 $\mathrm{H}_{2} \mathrm{O}_{2}$ 에 의한 $50 \%$ 의 세포사멸을 보이는 산화 스트레스 조건 $\left(\mathrm{IC}_{50}\right)$ 의 $\mathrm{H}_{2} \mathrm{O}_{2}$ 와 삼백초 추출 분획물이 포함된 배지에 세포를 24 시간 배양하여 생존율을 측정하여 세포 보호효과를 확인하였다. 결과분석은 실험군의 평균 OD $540 \mathrm{~nm}$ 값을 구하여 대조군( $100 \%$ 생존군) 의 평균 $\mathrm{OD} 540 \mathrm{~nm}$ 값에 대한 백분율로 환산하였다.

\section{MTT assay}

시료 처리된 $\mathrm{HDF}$ 세포 각각의 well에 MTT stock 용액(5 $\mathrm{mg} / \mathrm{ml}, \mathrm{PBS}$ )을 10 배로 희석하여 $100 \mu 1$ 를 처리한 후 $37^{\circ} \mathrm{C}$ 에서 2시간 동안 배양시켜 상등액을 제거하였다. 형 성된 MTT formazan 결정체를 dimethyl sulfoxide (DMSO)에 용해시켜 ELISA reader (Molecular devices, USA)로 formazan의 흡광 
도가 최대가 되는 test filter인 $540 \mathrm{~nm}$ 의 파장에서의 $\mathrm{OD}$ 값과 reference filter인 $630 \mathrm{~nm}$ 파장의 $\mathrm{OD}$ 값을 측정하여 그 차이 값의 흡광도를 구하였다.

\section{Real-time PCR}

삼백초 추출 분획물에 대한 fibulin-5의 mRNA 발현 분석 을 real-time PCR 방법으로 확인하였다. HDF 세포를 96-well micro plate에 접종 $\left(1 \times 10^{4} \mathrm{cell} / \mathrm{well}\right)$ 시키고 $5 \% \mathrm{CO}_{2}$ 의 배양기 에서 $37^{\circ} \mathrm{C}$ 로 24 시간 배양한 후, 삼백초 추출의 각 분획물이 함유하는 $10 \% \mathrm{FBS}$ 가 포함된 DMEM으로 배지를 교환하였다. 24시간 후 배양 상층액을 제거하고 total RNA purification kit 를 이용하여 total RNA를 분리한 후 RT-PCR을 수행하여 cDNA를 획득하였다. 발현량이 일정한 housekeeping 유전자 (내부표준)인 $\beta$-actin 유전자의 일부를 PCR로 증폭한 다음 일 정한 비율로 희석하여 표준자(standard)를 만들고 이를 샘플 의 cDNA와 함께 real-time $\mathrm{PCR}$ 을 시행하였다. 검량선(threshold; 증폭 효율 반영한 척도)을 토대로 얻어진 $\beta$-actin의 표준 곡선을 이용하여 샘플의 $\beta$-actin 유전자의 정량값을 구하였다. 표적 유전자에 대해서도 앞의 방법과 동일하게 표준자를 만들 어 샘플의 cDNA와 함께 real-time PCR을 수행하였다. 검량선 을 토대로 얻어진 표적 유전자의 표준곡선을 이용하여 표적 유전자의 정량값을 구하였으며, 각 샘플의 정량값을 $\beta$-actin의 정량값으로 나누어 real-time PCR에 사용한 샘플간의 오차를 보정하였다. 보정 후의 정량 결과를 토대로 샘플간의 대상 유 전자의 발현 상대값을 구하였다. $\beta$-actin의 primer (sense, 5'-GCCTCGCCTTTGCCGATCC-3'; antisense, 5'-CATCGTC GCCCGCGAAGCC-3')와 prove (5'-CCAGCTCACCATGG ATGGATGAT) 및 fibulin-5의 primer (sense, $5^{\prime}$-CATCTTG TACCGGGACATGGA-3'; antisense, 5'-CGTTTGCCGCATG TAAAATTCT-3')와 prove (5'-CAAATGCAAGCCACGACC CGCTACCCT-3')의 합성은 NCBI data base로부터 유전자의 전체 DNA 염기서열을 확보하여, 이를 바탕으로 primer3 프로 그램을 이용하여 선별 제작하였다. 특히 prove의 $5^{\prime}$ 에는 형광물 질 fam을 부착하고, $3^{\prime}$ 에는 소각물질(quencher)를 부착하였다.

\section{CAM assay}

유정란을 $\pm 90 \%$ 습도가 유지되는 $37^{\circ} \mathrm{C}$ 부화기에서 3 일간 배양하여(3 4일 배) 유정란의 볼록한 쪽에 작은 구멍을 똟고, 그 구멍을 통해 $18 \mathrm{gage}$ 주사바늘을 사용하여 약 $2 \mathrm{ml}$ 의 알부 민을 뽑아냈다. 공기주머니가 있는 쪽을 $70 \%$ 에탄올로 소독하 고 공기주머니 위쪽의 껍질을 수술용 칼로 잘라 핀셋으로 제 거한 후, 외피막(shell membrane)을 조심스럽게 벗겨내어 창 (window)을 낸 다음, 유리테이프로 봉하여 다시 부화기에 넣 어 배양하였다. 약 4.5 일 배가 되면 $\operatorname{CAM}$ (융모요막)이 직경 $3 \sim 5 \mathrm{~mm}$ 가 되고, 이때의 배를 CAM 분석법에 사용하였다. 시료 처리하기 하루 전에 thermanox coverslip를 멸균하여 말
린 다음, clean bench 안에서 삼백초 추출물의 분획 시료를 점적하여 UV를 켜두고 약 2시간을 방치하였다. 창의 유리테 이프를 떼어내고 시료가 도포된 thermanox coverslip을 4.5일 배의 CAM 표면에 도포된 면이 아래로 가도록 뒤집어 놓고 창을 유리테이프로 봉하여 부화기에서 배양하였다. 2 일의 추 가 배양 후 유리테이프를 떼어 내고 혈관형성 활성여부를 관 찰하였다.

\section{통계처리}

실험결과는 SPSS program (ver. 12.0.01)을 이용하여 실험 군당 평균 \pm 표준편차로 표시하였고 통계적 유의성 검정은 분 산분석(ANOVA test)을 한 후 $p<0.05$ 수준에서 Tukey's test를 이용하여 상호검정하였다.

\section{결과 및 고찰}

\section{삼백초 분획물의 수율}

삼백초 $200 \mathrm{~g}$ 에서 얻어진 $7.311 \mathrm{~g}$ 의 $\mathrm{MeOH}$ 추출물을 $n$ hexane, $\mathrm{CHCl}_{3}, \mathrm{EtOAc}, n-\mathrm{BuOH}$, 및 열수로 유기용매의 극성이 낮은 것부터 높은 순서로 순차 분획한 결과, 각 분획물의 수율 은 Table 1 과 같이 나타났다. 삼백초의 용매별 분획물 수율은 $n-\mathrm{BuOH} 0.51 \%, \mathrm{CHCl}_{3} 0.21 \%$ 그리고 $n$-hexane과 EtOAc에서 각각 $0.14 \%$ 의 가장 낮은 수율 및 열수 분획물에서 $1.56 \%$ 의 가장 높은 수율을 얻었다.

\section{삼백초 추출 분획물의 항산화 활성}

$\mathrm{DPPH}$ 는 짙은 자주색을 나타내며 그 자체가 질소 중심의 라디칼로 라디칼 전자의 비편재화에 의해 안정화된 상태로 존재한다. 용해된 $\mathrm{DPPH}$ 는 $517 \mathrm{~nm}$ 에서 최대 흡광도를 나타내 며, 시료의 환원력에 의한 흡광도 감소는 자유라디칼의 소거 반응이 진행됨을 알 수 있고 지질과산화의 초기반응의 억제정 도 예측 및 노화 억제작용의 척도로 이용되고 있다[1,13]. 따라 서 본 실험에서는 DPPH 자유라디칼 소거활성법을 이용하여 삼백초 추출 분획물이 직접 자유라디칼을 제거하는 항산화 활성을 측정하여 양성 대조구인 BHT와 비교하였다. 삼백초

Table 1. Yield of various organic solvent fractions obtained from the total $\mathrm{MeOH}$ extract ${ }^{1}$ of $S$. chinensis

\begin{tabular}{lcc}
\hline Solvent fractions & Dried weight $(\mathrm{g})$ & Yield $(\%)^{2}$ \\
\hline n-hexane & 0.289 & 0.14 \\
$\mathrm{CHCl}_{3}$ & 0.397 & 0.20 \\
$\mathrm{EtOAc}$ & 0.282 & 0.14 \\
$n$ - $\mathrm{BuOH}$ & 1.024 & 0.51 \\
$\mathrm{H}_{2} \mathrm{O}$ & 3.120 & 1.56 \\
\hline
\end{tabular}

${ }^{1} \mathrm{MeOH}$ extract $(7.311 \mathrm{~g})$ obtained from $200 \mathrm{~g}$ of $S$. chinensis. ${ }^{2}$ yield $(\%)=\frac{\text { Dried weight of solvent fractions }(\mathrm{g})}{\text { Dried weight of } S \text {. chinensis }(\mathrm{g})} \times 100$ 
Table 2. Absorbance change by DPPH radical scarvengeing activity of each fraction of $S$. chinensis

\begin{tabular}{|c|c|c|c|c|c|}
\hline Samples & Control & \multicolumn{4}{|c|}{ Fractions } \\
\hline Conc. $(\mu \mathrm{g} / \mathrm{ml})$ & BHT & $n$-Hexane & $\mathrm{CHCl}_{3}$ & EtOAc & $n-\mathrm{BuOH}$ \\
\hline 100 & $0.235 \pm 0.002^{\mathrm{ab}}$ & $0.832 \pm 0.099^{\mathrm{ac}}$ & $0.611 \pm 0.086^{\mathrm{ac}}$ & $0.249 \pm 0.030^{\mathrm{abc}}$ & $0.292 \pm 0.038^{\mathrm{ac}}$ \\
\hline 75 & $0.349 \pm 0.015^{\mathrm{a}}$ & $0.961 \pm 0.076^{\mathrm{a}}$ & $0.775 \pm 0.025^{\mathrm{a}}$ & $0.266 \pm 0.018^{\mathrm{a}}$ & $0.439 \pm 0.029^{a}$ \\
\hline 50 & $0.525 \pm 0.041^{\mathrm{a}}$ & $1.107 \pm 0.068^{\mathrm{a}}$ & $0.956 \pm 0.011^{\mathrm{a}}$ & $0.337 \pm 0.026^{\mathrm{a}}$ & $0.702 \pm 0.014^{\mathrm{a}}$ \\
\hline 25 & $0.696 \pm 0.090^{\mathrm{a}}$ & $1.287 \pm 0.048^{\mathrm{a}}$ & $1.088 \pm 0.076^{\mathrm{a}}$ & $0.548 \pm 0.044^{\mathrm{a}}$ & $1.039 \pm 0.031^{\mathrm{a}}$ \\
\hline
\end{tabular}

Blank: 1.397.

Values are mean $\pm S D, n=3$.

asignificantly different $\left({ }^{\mathrm{a}} p<0.01\right)$ by ANOVA test.

b \& c significantly different $\left({ }^{b} \& p<0.05\right)$ between groups by Tukey's test.

추출 분획물과 BHT를 각각 $25 \mu \mathrm{g} / \mathrm{ml}, 50 \mu \mathrm{g} / \mathrm{ml}, 75 \mu \mathrm{g} / \mathrm{ml}$, $100 \mathrm{\mu g} / \mathrm{ml}$ 농도로 제조하여 $0.2 \mathrm{mM}$ 의 $\mathrm{DPPH}$ 를 넣어 반응 후 감소하는 흡광도를 측정하여 얻은 자유라디칼 소거능을 살펴 본 결과를 Table 2에 나타내었다. 삼백초 추출 분획물의 각 농도가 증가할수록 흡광도가 감소하여 $\mathrm{DPPH}$ 의 자유라디 칼 소거활성이 유의성 있게 증가하는 경향을 보이므로 농도 의존적으로 항산화 효과를 나타내었다( $p<0.01) .100 \mu \mathrm{g} / \mathrm{ml}$ 농 도의 대조구인 $\mathrm{BHT}$ 와 동량의 삼백초 추출 $\mathrm{EtOAc}$ 분획의 비 교에서 0.235 와 0.249 의 낮은 흡광도를 나타내어 삼백초 추출 의 EtOAc 분획은 BHT와 유사한 소거활성과 다른 분획물 보 다 상대적으로 높은 항산화 활성물질을 포함하고 있음을 알 수 있다. 또한 전자공여능(EDA)에 의해 얻은 각 분획별 $\mathrm{ED}_{50}$ 은 BHT의 $27.22 \mu \mathrm{g} / \mathrm{ml}$ 보다 삼백초 추출의 $\mathrm{EtOAc}$ 분획에서 $12.84 \mu \mathrm{g} / \mathrm{ml}$ 로 가장 높았으며, $n-\mathrm{BuOH}, \mathrm{CHCl}_{3}, n$-hexane 분 획에서도 각각 $48.07 \mu \mathrm{g} / \mathrm{ml}, 89.96 \mu \mathrm{g} / \mathrm{ml}, 131.78 \mu \mathrm{g} / \mathrm{ml}$ 의 $\mathrm{ED}_{50}$ 값을 보였다(Fig. 2). 김 등[14]이 삼백초를 에탄올 농도별 및 물로 추출하였을 경우, $40 \%$ 에탄올 추출물로 4 시간 추출이 항산화 활성 및 총 플라보노이드 함량을 높일 수 있는 추출용 매 조건임을 제시하였고, 본 실험에서는 삼백초의 $\mathrm{MeOH}$ 추 출에 의한 $\mathrm{EtOAc}$ 분획에서 항산화 활성물질이 다량 함유되어 있는 것을 알 수 있었다. 이와 같은 결과는 삼백초에 함유된 항산화 활성물질은 특정 용매에만 용해되지 않고 다른 용매에 도 용해되는 성분으로 복합적인 특성을 가지며, 또한 추출 조 건에 따라 항산화 활성물질의 함량 변화가 있는 것으로 생각 된다.

\section{삼백초 추출 분획물의 세포에 대한 독성 평가}

삼백초 추출 분획물이 정상세포인 $\mathrm{HDF}$ 세포의 생존율에 어떤 영향을 미치는지 알아보기 위하여 $20 \mu \mathrm{g} / \mathrm{ml}, 40 \mu \mathrm{g} / \mathrm{ml}$, $60 \mathrm{\mu g} / \mathrm{ml}$ 농도별 분획물을 $\mathrm{HDF}$ 세포 $\left(1 \times 10^{5} \mathrm{cell} / \mathrm{ml}\right)$ 에 48 시 간 처리하여 배양한 결과, 농도가 증가하여도 독성은 나타내 지 않았으며 세포의 생장에도 어떠한 영향을 미치지 않았다 (Fig. 3A). 이는 Seo 등[31]이 삼백초의 ethanol 추출에 의한 용매별 분획물이 정상세포인 DC2.4 인간의 면역력 세포의 생 육에 영향을 미치지 않았던 연구 결과와 일치한다. 또한 삼백

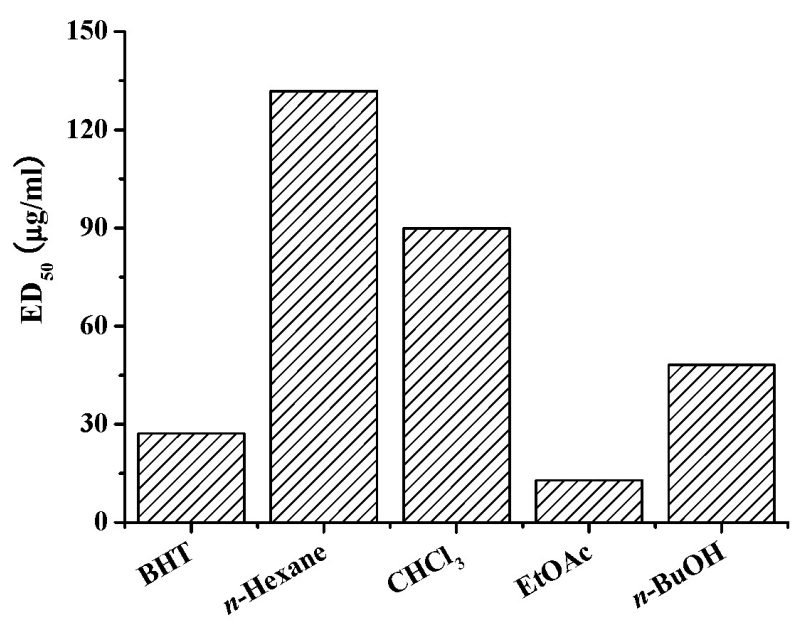

Fig. 2. DPPH free radical scavenging activity in various solvents fraction of $S$. chinensis.

초 추출물이 암세포의 생육을 억제시키는 세포독성 [5,24]은 향 후 새로운 암 예방 및 항암 식의약품의 소재로 개발 가능성을 제시한다. 한편 Borefreund와 Puerner[7]의 독성판정 기준에 의하여 강독성인 것으로 나타난 $\mathrm{H}_{2} \mathrm{O}_{2}$ 를 10 100 $\mathrm{MM}$ 로 $\mathrm{HDF}$ 에 처리하여 세포의 증식을 $50 \%$ 억제하는 $\mathrm{H}_{2} \mathrm{O}_{2}$ 농도 $\left(\mathrm{H}_{2} \mathrm{O}_{2}\right.$ $\mathrm{IC}_{50}=21.4 \mu \mathrm{g} / \mathrm{ml}$ ) 값인 $20 \mu \mathrm{M}$ (Fig. 3B)를 기준으로, 활성산소 에 의한 세포독성에 대하여 삼백초 추출 분획물의 세포 보호 효과를 확인하였다.

\section{$\mathrm{H}_{2} \mathrm{O}_{2}$ 에 의해 유도된 세포독성에 대한 삼백초 추출 분획물} 의 보호효과

$\mathrm{H}_{2} \mathrm{O}_{2}$ 에 의해 유도된 활성산소의 $\mathrm{HDF}$ 세포독성에 대한 삼 백초 추출 분획물의 보호효과는 선행실험(Fig. $3 \mathrm{~B})$ 의 $\mathrm{H}_{2} \mathrm{O}_{2}$ $\mathrm{IC}_{50}$ 값인 $20 \mu \mathrm{M}$ 의 $\mathrm{H}_{2} \mathrm{O}_{2}$ 농도에 삼백초 추출 분획물을 $50 \mu \mathrm{g} /$ $\mathrm{ml}$ 농도로 처리하여 24시간 후 세포 생존율을 측정하였다(Fig. 4). 다른 분획에 비하여 직접 자유라디칼을 제거하는 항산화 활성이 가장 높았던 삼백초 추출의 $\mathrm{EtOAc}$ 분획에서 $\mathrm{H}_{2} \mathrm{O}_{2}$ $\left(\mathrm{IC}_{50}\right)$ 에 의해 유도된 $\mathrm{HDF}$ 세포의 독성에 대한 현저한 보호효 과를 나타내었다. $\mathrm{H}_{2} \mathrm{O}_{2}\left(\mathrm{IC}_{50}\right)$ 처리군 세포 생존율은 다른 분획 
(A)

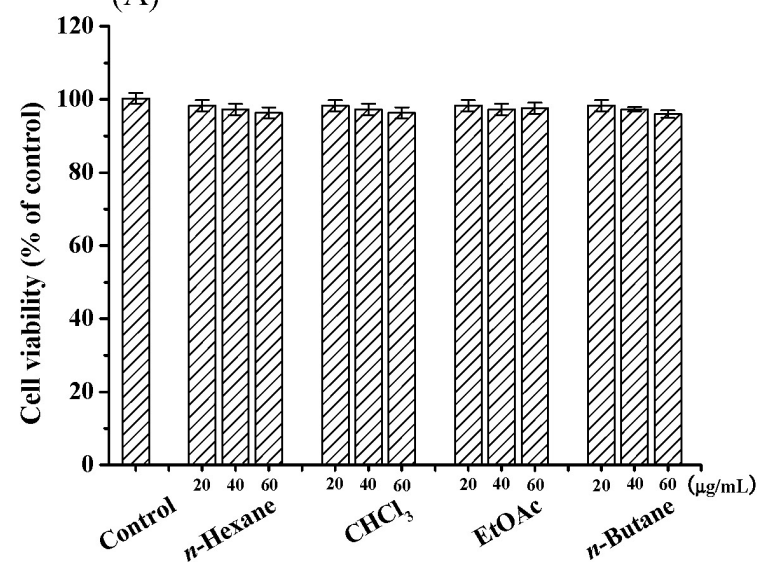

(B)

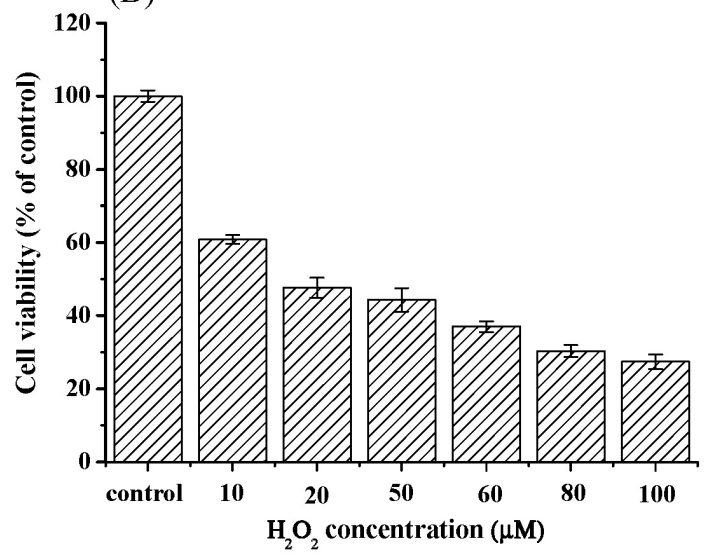

Fig. 3. Concentration-dependent effects of fractions from $S$. chinensis extract (A) or $\mathrm{H}_{2} \mathrm{O}_{2}$ (B) on $\mathrm{HDF}$ cell growth. Cells were treated with different concentration of each fraction or $\mathrm{H}_{2} \mathrm{O}_{2}$ as indicated in material and methods. Cell viability was analyzed using the MTT assay. The date indicated the mean $\pm \mathrm{SD}$ for triplicate experiments.

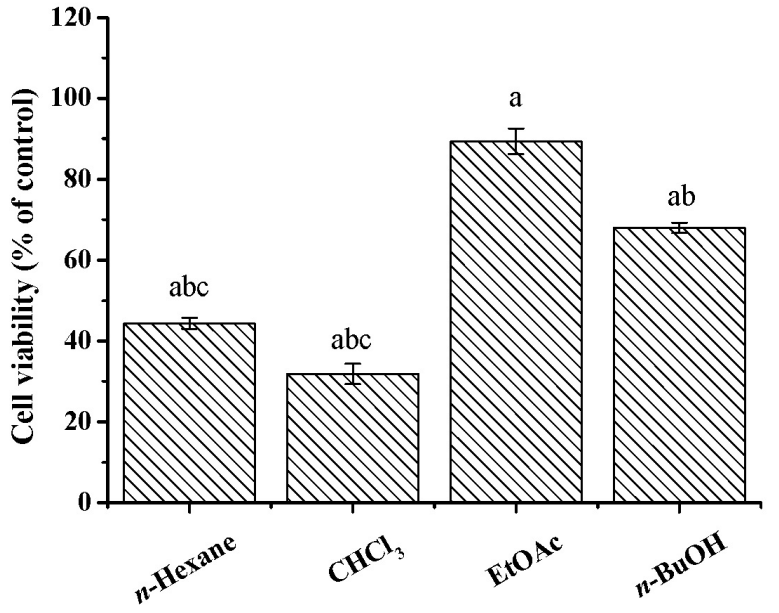

Fig. 4. Effects of fractions from $S$. chinensis extract on $\mathrm{H}_{2} \mathrm{O}_{2}$-induced HDF cell death. Cells were treated with $50 \mu \mathrm{g} / \mathrm{ml}$ concentration of each fraction and $20 \mu \mathrm{M} \mathrm{H} \mathrm{H}_{2} \mathrm{O}_{2}$ as described in material and methods. Viable cells were analyzed using the MTT assay. Each value represent the mean \pm SD. ${ }^{a}$ Significant different $\left({ }^{a} p<0.01\right)$ by ANOVA test. ${ }^{b}$ Significant different $\left({ }^{b} p<0.01\right)$ from EtOAc by Tukey's test. 'Significant different $\left({ }^{\mathrm{c}} p<0.01\right)$ from $n$-BuOH by Tukey's test.

보다 유의성 있게 EtOAc 분획에서 $89.39 \%$ 로 가장 높게 나타 났으며, 다음으로 $n-\mathrm{BuOH}$ 분획에서도 $67.98 \%$ 의 세포 보호효 과를 나타내었다. 삼백초의 주성분인 quercetin, quercitrin 등 은 프라본(flavone) 계열로, quercetin은 항균, 항산화, 항암성 및 모세혈관 강화작용 등의 효과들이 알려져 있는 바와 같이 $[14,31]$, 본 연구의 $\mathrm{MeOH}$ 추출에 의한 $\mathrm{EtOAc}$ 와 $n \mathrm{BuOH}$ 분획 에 이러한 물질들이 함유되어 항산화 활성에 의한 세포 보호 효과를 나타내는 것으로 보인다. 또한 Park 등[27]이 삼백초의

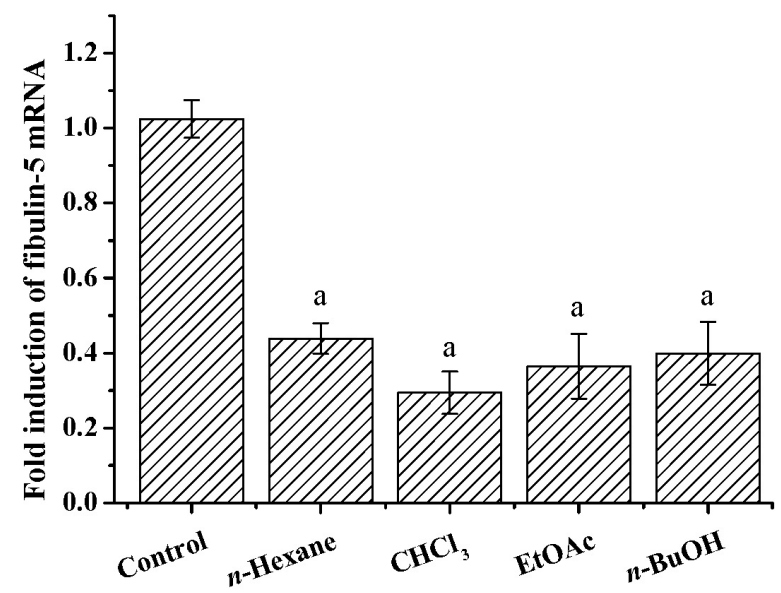

Fig. 5. Effects of fraction from S. chinensis extract on expression of fibulin- 5 gene. HDF cells were cultured in the serum free medium for $12 \mathrm{hr}$ followed by treatment with each fraction from $S$. chinensis extract. Fibulin-5 mRNA expression was analysed by real-time PCR as described in material and methods. The data represent the mean \pm SD of triplate experiments. ${ }^{a}$ Significant different $\left({ }^{a} p<0.05\right)$ from control group by Tukey's test.

물과 $\mathrm{MeOH}$ 추출물이 카드뮴(cadmium)에 의한 NIH 3T3 섬 유모세포의 독성을 완화 하였음에서 알 수 있듯이 삼백초의 이러한 성분들이 해독의 효능이 있음을 알 수 있다. 한편 삼백 초 추출의 $\mathrm{CHCl}_{3}, n$-hexane 분획 $(50 \mu \mathrm{g} / \mathrm{ml})$ 은 세포 생존율이 $50 \%$ 이하로 나타나 세포 보호효과가 없는 것으로 확인하였다.

Fibulin-5 mRNA 발현율 분석

피부는 산소와 접촉하고 자외선에 노출되어 있어 ROS에 의한 피부의 광산화적 손상[24]과 노화 과정에서 탄력 섬유 
(A)

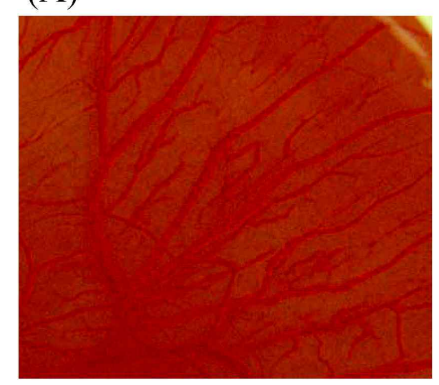

(B)

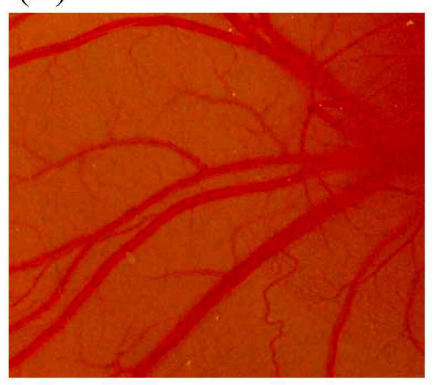

(C)

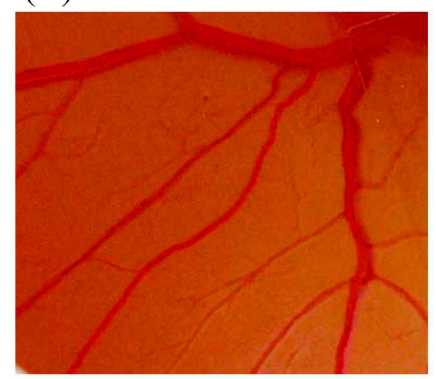

Fig. 6. Anti-angiogenesis effects for EtOAc fraction from $\mathrm{MeOH}$ extract of $S$. chinensis in the CAM assay. The CAM was visualized with $10 \%$ fat emulsion 2 days after sample implantation. (A), 20\% DMSO negative control; (B), EtOAc fraction (2 $\mu \mathrm{g} / \mathrm{egg})$; (C), Retinoic acid positive control (2 $\mu \mathrm{g} / \mathrm{egg})$.

(elastic fiber)의 손실[3] 등이 주름생성의 주원인이 되고 있다. 탄력 섬유의 발달에 필수적인 단백질로 엘라스틴(elastin)이 있으며, 엘라스틴 형성의 핵심이 되는 단백질이 최근 fibulin-5 (developing arteries and neural crest EGF-like, DANCE)로 동정되었다[23,34]. 암세포는 영양과 산소를 자체조달하기 위 해 혈관내피성장인자(vascular endothelial growth factor, VEGF)를 포함, 특수한 분자들을 방출해 새로운 혈관을 만들 게 한다. Fibulin-5 단백질이 두 가지 방법으로 암세포의 이러 한 활동을 차단하는데, 그 하나는 혈관내피세포에 대해 새로 이 들어오는 VEGF에 신경을 쓰지 말도록 명령하는 것이며 또 하나는 이와 동시에 새로운 혈관형성을 억제하는 자연단백 질인 thrombospondin-1의 분비를 증가시키는 것이다. 즉 새 로운 혈관을 만들어 영양공급원을 확보하려는 암세포의 움직 임에 브레이크를 거는 것으로 하나의 분자가 이처럼 두 가지 기능을 하는 것은 흔치 않은 일이다[2]. 본 실험에서는 항산화 활성을 갖는 삼백초 추출 분획물이 탄력섬유인 엘라스틴 형성 의 핵심이며, 혈 관형성 억제기능을 갖는 fibulin-5의 발현에 미치는 영향 여부를 조사하였다(Fig. 5). 삼백초 추출 분획물이 처리된 $\mathrm{HDF}$ 세포로부터 fibulin-5의 mRNA 발현 변화 분석을 real-time PCR 방법으로 확인한 결과, 모든 분획에서 유의성 $(p<0.05)$ 있게 발현이 감소되었으나 분획간에서는 fibulin-5의 $\mathrm{mRNA}$ 발현에 큰 차이를 보이지는 않는 것으로 나타났다.

\section{혈관형성 억제활성}

항산화 활성을 갖는 물질이 다량 함유되어 있는 삼백초 추 출물의 $\mathrm{EtOAc}$ 분획이 혈관형성에 미치는 영향을 관찰하기 위 하여 CAM assay 분석실험을 실시하였다(Fig. 6). 양성대조군 으로 혈관형성의 억제활성을 갖는 것으로 알려진 retinoic acid [12]와 비교한 결과 동량인 $2 \mu \mathrm{g} / \mathrm{egg}$ 의 삼백초 추출물의 $\mathrm{EtOAc}$ 분획에서 혈관형성이 억제됨을 관찰하였으며(Fig. 6B), 이는 Yoo 등[35]이 삼백초의 ethanol 추출물에서 농도 의존적 으로 혈관형성이 억제된 결과와 유사함을 보였다. 이러한 결
과는 삼백초 추출물의 $\mathrm{EtOAc}$ 분획이 항산화 활성 및 해독은 물론 혈관형성의 억제 인자로도 작용함을 알 수 있다.

\section{감사의 글}

본 연구는 2008년도 호서대학교의 재원으로 학술연구비 지원을 받아 수행된 연구임(20080166).

\section{References}

1. Aberer, W., Anderson, K. E. and White, I. R. 1993. Should patch testing be restricted to dermatologists only. Contact Dermatitis 28, 1-2.

2. Albig, A. R. and Schiemann, W. P. 2004. Fibulin-5 antagonizes vascular endothelial growth factor (VEGF) signaling and angiogenic sprouting by endothelial cells. DNA Cell Biol. 23, 367-379.

3. Albig, A. R. and Schiemann, W. P. 2005. Fibulin-5 function during tumorigenesis. Future Oncol. 1, 23-35.

4. Aruoma, O. I. 1994. Nutrition and health aspects of free radicals and antioxidants. Food Chem Toxicol. 32, 671-683.

5. Bang, K. S. 2008. Cytotoxic and antioxidative effects of Saururus chinensis. J. Cosm Public Health 4, 220-225.

6. Blois, M. S. 1958. Antioxidant determination by the use of a stable free radical. Nature 26, 1199-1200.

7. Borenfreund, E. and Puerner, J. A. 1984. A simple quantitative procedure using monolayer culture for cytotoxicity assay (HTD/NR-90). J. Tiss. Cult. Meth 9, 7-9.

8. Cho, H. Y., Cho, C. W. and Song, Y. S. 2005. Antioxidative and anti-inflammatory effects of saururus chinensis methanol extract in RAW 264.7 macrophages. J. Med Food 8, 190-197.

9. Davies, K. F. and Goldberg, A. L. 1987. Proteins damaged by oxygen radicals are rapidly degraded in extracts of red blood cells. J. Biol. Chem 262, 8227-8261.

10. Fubini, B. 1998. Surface chemistry and quartz hazard. Ann. Occup. Hyg. 42, 521-530.

11. Halliwell, B. J. and Gutteridge, M. C. 1984. Oxygen toxicity, 
oxygen radicals, transition metals and disease. Eur. J. Biochem 219, 1-14.

12. Iurlaro, M., Benelli, R., Masiello, L., Rosso, M., Santi, L. and Albini, A. 1998. Beta interferon inhibits HIV-1 Tat-induced angiogenesis synergism with 13 -cis retinoic acid. Eur. J. Cancer 34, 570-576.

13. Kameyama, K., Takemura, T., Hamada, Y., Sakai, C., Kondoh, S., Nishiyama, S., Urabe, K. and Hearing, V. J. 1993. Pigment production in murine melanoma cells is regulated by tyrosinase. tyrosinase-related protein 1 (TRP 1) dopachrome tautomerase (TRP 2) and a melanogenic inhibitor. J. Invest. Dermatol. 100, 126-131.

14. Kim, S. K., Ban, S. Y., Kim, J. S. and Chung, S. K. 2005. Change of antioxidant activity and antioxidant compounds in Saururus chinensis by extraction conditions. J. Korean Soc. Appl. Biol. Chem 48, 89-92.

15. Koh, M. S. 2004. Antimicrobial activity of Saururus chinensis Baill extract. J. Korean Soc. Food Sci. Nutr. 33, 1098-1105.

16. Kumaran, A. and Karunakaran, R. J. 2006. Antioxidant and free radical scavenging activity of an aqueous extract of Coleus aromaticus. Food Chem 97, 109-114.

17. Kwak, J. W. and Kwon, C. H. 1988. Pharmacological studies on Saururus chinensis Baill. Bull. KH Pharma. Sci. 16, 137-154.

18. Kwon, H. J., Jung, U., Park, H. R., Shin, D. H. and Jo, S. K. 2007. Effects of gamma irradiation on color changes and antioxidative ctivities of Caesalpinia sappan L. J. Korean Soc. Food Sci. Nutr. 36, 1055-1061.

19. Lee, J. T., Jung, S. H., Jo, W. A., Kang, B. Y., Choi, E. Y., Jung, Y. S. and Son, A. R. 2005. A study on the materials of functional korean herb cosmetics using atractylodis Rhizoma Alba and Saururi herba seu Radix. Korean J. Oriental Med 5, 7-14.

20. Lee, S. T., Park, J. M., Lee, H. K., Kim, M. B., Cho, J. S. and Heo, J. S. 2000. Component comparison in different growth stages and organs of Saururus chinensis Baill. Korean J. Medicinal Crop Sci. 8, 312-318.

21. Lee, S. T., Lee, Y. H., Choi, Y. J., Lee, Y. H., Cho, J. S. and Heo, J. S. 2001. Yield and bioactive compponent on different compost amounts and cultural methods of Saururus chinensis Baill. Korean J. Medicinal Crop Sci. 9, 220-224.

22. Maeura, Y., Weisburger, J. H. and Williams, G. 1984. Dose-dependent reduction of N-2-fluorenylacetamide-induced liver cancer and enhancement of bladder cancer in rats by butylated hydroxytoluene. Cancer Res. 44, 1604-1610.

23. Nakamura, T., Lozano, P. R., Ikeda, Y., Iwanaga, Y., Hinek, A., Minamisawa, S., Cheng, C. F., Kobuke, K., Dalton, N., Takada, Y., Tashiro, K., Ross Jr, J., Honjo, T. and Chien,
K. R. 2002. Fibulin-5/DANCE is essential for elastogenesis in vivo. Nature 415, 171-175.

24. Park, D. J. and Lee, J. C. 2008. A study on the antioxidative and depigmentation activities of the ethanol extract of Saururus herba. Korean J. Herbology 23, 193-202.

25. Park, J. H. and Lee, J. G. 2000. The encyclopedia of medicinal plants. pp. 202-203, Shin il publishing Co., Seoul, Korea.

26. Park, J. H., Park, B. G., Kim, M. J., Park, S. G. and Kim, J. H. 1998. Effects of tuber pasition and number of nodes on growth of Saururus chinensis Baill. Korean J. Medicinal Crop Sci. 6, 286-293.

27. Park, S. J., Yoo, H. J., Choi, H. S., Seo, B. Y., Yang, S. H., Kim, Y. H., Jeong, J. Y. and Lee, K. N. 2004. Effect of Saururus chinensis Baill extracts on antibacterial activity and cadmium induced cytotoxicity. Korean J. Oriental Prev. Med Society 8, 81-98.

28. Park, S. K., Oh, G. J., Kim, H. T., Kim, H. J., Chung, S. G. and Cho, E. H. 1998. Analgesic constituent from the Herba of Saururus chinensis (Lour.) Baill. Yakhak Heoji 42, 238-242.

29. Pontieri, V. and Sage, T. L. 1999. Evidence for stigmatic self incompatibility, pollination induced ovule enlargement and transmitting tissue exudates in the paleoherd, Saururus cernuus L. (Saururacese). Ann. Bot. 84, 507-519.

30. Rehman, Z., Habbib, F. and Shah, W. H. 2004. Utilization of potatopeels extract as a natural anti-oxidant in bean oil. Food Chem 85, 215-220.

31. Seo, H. S., Chung, B. H. and Cho, Y. G. 2008. Antioxdant and anticancer effects of agrimony (Agrimonia pilosa L.) and chinese lizardtail (Saururus chinensis Baill). Korean J. Medicinal Crop Sci. 16, 139-143.

32. Shin, H. H., Kang, M. J., Cho, H. Y., Kim, B. C. and Cho, E. K. 2008. Optimization of extraction conditions for Houttuynia cordara Thunb and Saururus chinensis Baill mixture by response surface methodology. Food Eng. Prog. 12, 247-255.

33. Valko, M., Rhodes, C. J., Moncol, J., Izakovic, M. and Mazur, M. 2006. Free radicals, metals and antioxidants in oxidative stress induced cancer. Chem Biol. Interact. 160, 1-40.

34. Yanagisawa, H., Davis, E. C., Starcher, B. C., Ouchi, T., Yanagisawa, M., Richardson, J. A. and Olson, E. N. 2002. Fibulin-5 is an elastin-binding protein essential for elastic fiber development in vivo. Nature 415, 168-171.

35. Yoo, H. J., Kang, H. J., Jung, H. J., Kim, K. H., Chang, J. L. and Park, E. H. 2008. Anti-inflammatory, anti-angiogenic and anti-nociceptive activities of Saururus chinensis extract. J. Erthnopharmacol. 120, 282-286. 


\section{초록 : 삼백초(Saururus chinensis) 추출물의 항산화능 및 생리활성 연구}

강창수 ${ }^{1}$ 이민주 ${ }^{1}$ 박철범 ${ }^{2} \cdot{\text { 방인석 }{ }^{1} \star}^{2}$

( ${ }^{1}$ 호서대학교 생명과학과, ${ }^{2}$ 호서대학교 융합기술연구소)

약용소재로 사용되고 있는 삼백초의 잎과 줄기로부터 유기 용매의 극성에 따른 순차적 분획물을 얻어 항산화 효과와 연관하여 피부의 탄력 및 혈관형성에 미치는 영향을 조사하였다. 삼백초 추출 분획물에 대한 항산화 활성 은 시료의 농도가 증가할수록 $\mathrm{DPPH}$ 에 대한 전자공여능도 증가하였으며, $\mathrm{ED}_{50}$ 은 $\mathrm{EtOAc}$ 분획에서 합성 항산화제 인 BHT의 $27.22 \mu \mathrm{g} / \mathrm{ml}$ 보다 $12.84 \mu \mathrm{g} / \mathrm{ml}$ 로 높게 나타났다. 또한 $\mathrm{H}_{2} \mathrm{O}_{2}$ 에 의해 유도된 $\mathrm{HDF}$ 세포사멸( $\left(\mathrm{IC}_{50}\right)$ 에 대하 여 삼백초 추출 $50 \mathrm{\mu g} / \mathrm{ml}$ 의 $\mathrm{EtOAc}$ 분획에서 $89.39 \%$ 의 가장 높은 세포 생존율을 나타내었으며, 동량의 $n-\mathrm{BuOH}$ 분획에서도 $67.98 \%$ 의 유의적인 세포 생존율을 보였다. 한편 삼백초 추출 분획물은 피부 탄력과 관련있는 fibulin-5 mRNA의 발현율을 감소시켰으며, 항산화 활성이 높은 삼백초 추출 EtOAc 분획에 대한 CAM assay 결과, 혈관형성을 억제하는 것으로 나타났다. 이러한 삼백초 추출 $\mathrm{EtOAc}$ 분획은 향후 항산화 활성 및 해독과 관련된 혈관형성 억제의 약재개발 가능성이 있음을 암시하는 것으로 이의 작용기작에 대한 더욱 자세한 연구가 필요하 다고 생각한다. 